Regional and Business Studies (2020) Vol 12 No 2, 17-32

Szent István University Kaposvár Campus, Faculty of Economic Science, Kaposvár doi: $10.33568 /$ rbs. 2516

\title{
From Analogue to Digital Banking: DEVELOPMENTS IN THE EUROPEAN UNION FROM 2007 TO 2019
}

\author{
Michael MenRad, József VARGA \\ Szent István University Kaposvár Campus, H-7400 Kaposvár, Guba Sándor u. 40.
}

\section{ABSTRACT}

Research on banking regularly assumes that digitalisation has an impact on banking. This blanket assumption is not erroneous, but it is too inaccurate, too undifferentiated and probably only applies in the long term. Results of this study show that the customers' habits and requirements and thus the willingness to accept digital technologies in the banking sector are changing within a significantly different speed. The spread ranges from almost complete use, as in Scandinavia, dynamic development, as in the Czech Republic and Greece, to almost complete rejection, as in Bulgaria and Romania. This paper examines and demonstrates the influence of various socio-demographic and emotional characteristics on the use of digital media. Shifts in customer behaviours are revealed and discrepancies are identified by time series analyses and factor analyses. The results reveal the forthcoming death of the bank branch network accompanied by a regionally varying acceptance of Internet and mobile banking. This area of tension requires banks to have a good understanding of customer requirements regarding the demand for digitisation in order to avoid misguided decisions. However, the bank's side in the adoption process of new technologies by customers has been neglected by scientific studies so far. In order to measure the state of digitisation of banking services, a comparison equation is presented that allows banks to be benchmarked in terms of the degree of digitisation and enables banks to dynamically track changes in their customer portfolios.

Keywords: Adoption of technologies, distribution channels, financial services and technology, Internet and mobile banking

\section{INTRODUCTION}

Whereas customers used to seek access to their bank advisor through branches and preferred a local relationship, this behaviour has changed significantly in recent years, although it is not equally intense and synchronized everywhere. It is noticeable that the branch density has been considerably reduced and bank customers seem to be looking for other routes to their financial institutions. To obtain an overview of whether the transition from the analogue banking business to digital is proceeding in the same way, this paper examines the banking market in the European Union (EU).

Digital banking has provided a significant impetus for change in banking, as it has shifted the ways in which customers access a bank. The popularity of mobile 
phones and tablets and the high usage rates of customers gave rise to the demand for banking products linked to these forms of mobile communication. In the meantime, the mobile phone has been established in the banking business and new banking and customer solutions are increasingly being offered via this channel. In order to examine the significance of the changes in customers' access points to the bank, this study first analyses the banks' branch density to gain clarity on the access channel preferred by customers so far. Frequently, it is assumed that digitalisation affects all customers equally. In order to analyse this aspect in more details, this study examines factors influencing different levels of acceptance. It is elementary for banks to understand why customers are changing their access to banks and which customer groups are looking for these ways now and in the future. Existing literature examines this issue from the customers' perspective and neglects the banks' perspective. Banks usually react late to changing customer requirements and are therefore increasingly in competition with new competitors who have often recognised this demand earlier. For this reason, in addition to proximity to the customer, dynamic controlling of one's own customer portfolio is extremely important in order to be able to perceive changes immediately and react to them promptly. This study provides key figures that enable banks to dynamically review their customer portfolios and to control and benchmark their own level of digitalisation.

\section{LITERATURE REVIEW}

Points of contact with customers in the banking business are comparable to those in the retail and wholesale trade, although the banking business provides services and the retail and wholesale business offers goods. The standard customer interfaces in the banking business are either stationary (e.g. branch office, mobile field service) or virtual (e.g. Internet banking, mobile banking, telephone banking) (Sousa \& Voss, 2004). Digitalisation enables banks to network their distribution channels and customer touchpoints holistically in order to create added value for bank customers (Menrad, 2020). In this respect, there is no fundamental difference between the different sectors, although in banking, compared to retail and wholesale where the decline in branch numbers occurred earlier, bank branches continued to be frequented by customers. Past literature discussed on the one hand the marketing of services in comparison to physical goods and, on the other hand the identification of specific marketing strategies to deal with the problems posed by the unique characteristics of services (McKechnie, 1992). Both aspects are still highly relevant in the marketing of banking services. Services differ in general essentially from goods and face other problems because of different rules and laws. Service marketing is completely different to the marketing of goods as well - but first and foremost the feeling is sold in both cases - and requires own service marketing solutions (Zeithaml et al., 1985). Even though services and goods still have intersections, they essentially differ in intangibility, inseparability, heterogeneity and transience (McKechnie, 1992). According to the European Commission, a financial service means any service of a banking, credit, 
insurance, personal pension, investment or payment nature (European Parliament and Council, 2002). This very general definition by the European Parliament shows the wide scope of banking services, which often lead customers to contact their advisor with questions (Walter, 2003). For this reason, customers used bank branches to discuss solutions in the past in an environment that allows a high degree of interaction (Black et al., 2002). Banking services are not directly comparable to those of competitors because many factors have an impact on quality, performance, liability and security. If the criteria are determined, however, they can be comparatively well objectified and compared schematically (Messerschmidt et al., 2010). Product channel selection in the financial business is highly influenced by consumers themselves, the financial services requested, the characteristics of the channel and the reputation of the organization (Black et al., 2002). The product complexity and the perceived product risk tend to lead the customer directly to the local advisor. Further criteria are accessibility, channel costs and channel risks that influence channel selection positively or negatively depending on the fulfilment. Essential for the use of the channels is on the one hand confidence but also the age of the customers on the other hand. Younger customers tend to use novel forms of distribution, while wealthier and older customers prefer the face-to-face contact. Shopping motives and social motives are relevant for the product channel selection as well. While social motives tend to increase the use of branches, shopping motives lead to the most convenient channel for the customer. The organization itself and its image as well as size are further relevant aspects for the selection (Black et al., 2002).

Digital change and the achievements of digital communication do not stop at the banking business. On the contrary, the effects have a very significant impact on the banking business. Research and development $(\mathrm{R} \& \mathrm{D})$ have often been neglected in the banking business. Digitalisation has initiated a process that pushes R\&D in banking to a more advanced level, but it also involves the dangers of disruptive developments (Christensen et al., 2015). In terms of process flows, digitalisation has a profound influence on the core banking process (from the front office to the back office) (Gasser et al., 2017). Digitalisation is a factor inherent of progress and science. Digitalisation is discussed in the current literature in this context over the aspect of adoption of new technologies. It is understandable, since the process of analogue to digital banking must be assumed first. Competing theoretical approaches examined the determinants of the acceptance of new technologies. Different models were developed and analysed in the past. Conceptually, two essential directions (two major theories') can be separated. One of them is, Innovation Diffusion Theory (IDT) based on Roger's model considerations (Rogers, 1962; Tornatzky \& Klein, 1982) and on the other one is an essential representative in this research direction, the Technology Acceptance Model (TAM) (Davis, 1989). Various other models partly chronologically before TAM such as Theory of Reasoned Action (TRA) by Fishbein and Ajzen (1975), TAM2 by Venkatesh and Davis (2000), Theory of Planned Behavior (TPB) by Ajzen (1985) and Decomposed Theory of Planned Behavior (DTPB) by Taylor and Todd (1995) are related to TAM and deal with similar factors. New models 
are increasingly addressing the issues of trust and risk for bank clients. Probably the most complete model in existence today is DTPB, as it provides a clear understanding between attitudes and intentions, however, the above models IDT and TAM are most used in various new studies. Meanwhile, both models IDT and TAM, but also many other models listed above are also linked to each other via various papers and among different regression analyses.

The research in the field of adoption of new technologies is unbroken and has been strongly nourished by digitalisation. Hanafizadeh et al. (2014) had identified research gaps related to adoption of new technologies in banking business, which still exist and are to be supplemented as follows: (1) Factors influencing digital banking adoption in less developed regions and regions with subjectively low perceived IT security; (2) Discussing descriptive variables like demographics, socio-cultural, political factors and others, which impact to technology adoption; (3) Customer adoption to omni-channel distribution, new deployed media, in particular mobile phones, virtual reality and augmented reality as well as experience with smart data in banking; (4) Using further, less frequently used theories to explain technology adoption or even more advanced ones; (5) Broadening of perspectives such as the corporate customer perspective.

Based on these research gaps, the following hypotheses are examined in this paper to further explore the relevance of new technologies in this context for the banking business.

$\mathrm{H} 1$ : Banks reduce regional access to their customers

$\mathrm{H} 2$ : Internet banking is increasingly used by customers

H3: Sociodemographic characteristics can influence Internet banking usage

H4: Digital banking is used regionally with varying intensity

Data analysis below provides insight into whether customer behaviour is changing as a result of the increasing degree of digitalisation. As the focus of research so far has been on the customer side, the focus of this study is on the banks, as a comparative equation is used to show how the banks can measure their level of digitalisation.

\section{MATERIALS AND METHODS}

This study is quantitative in nature and the underlying data are secondary data from publicly available data sources. In order to conduct this data analysis, the data sources European Banking Federation, Eurostat and The World Bank were researched to obtain data on customer behaviours and banks. Time series and factor comparisons were conducted on the basis of these data. In order to gain a deeper understanding of the transformation in the banking business and to analyse the evolution from an analogue to a digital business, the authors started by examining the development of existing bank branches in the EU. For this purpose, available data were obtained from the European Banking Federation and the development was analysed over a time series. To be able to estimate the further development, a polynomial regression over the existing time series was conducted. The results show a significant change in the banks' branch network and thus a shift in customer access to the banks. 
Thereafter, the authors examined the development of customer acceptance of Internet banking within the EU. For this purpose, the authors used secondary data from Eurostat to reveal customer behaviours by means of a quantitative time series analysis and descriptive factor comparisons. As digitalisation for bank customers is very strongly linked to mobile banking activities, the authors have expanded granularity by further data analysis using The World Bank data and have drawn up further data comparisons.

In order to exclude a distortion due to the 2008 financial crisis, data from 2007 onwards were included.

\section{RESULTS}

The authors considered the traditional branch banking to be the analogue banking since the face-to-face contact to the customer and not the digital communication is the primary issue. The object of investigation was the total number of bank branches (Figure 1).

\section{Figure 1}

\section{Bank branches in the European Union, 2007-2019}

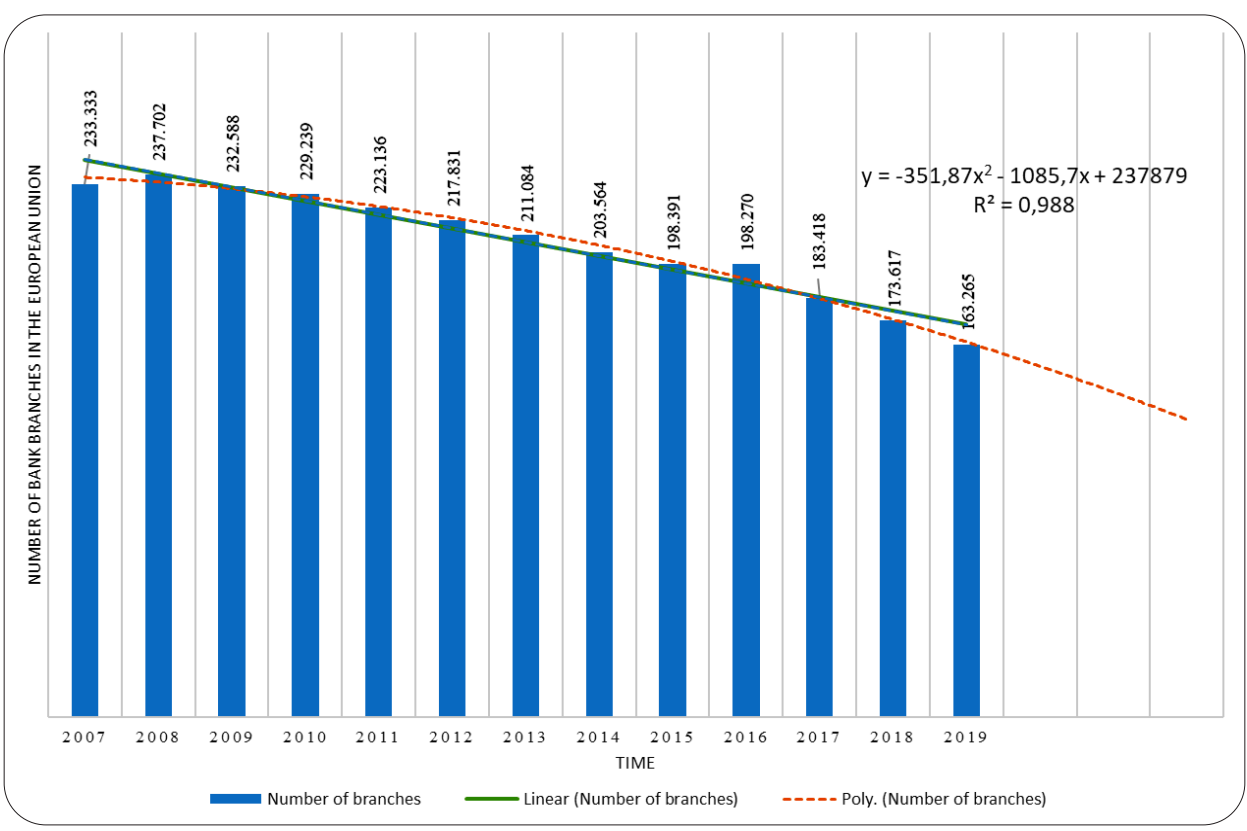

Source: Based on European Banking Federation (2020)

We have measured a polynomial regression of degree 2 over the existing time series in order to be able to assess the further development and to determine the point at which 
all bank branches in the EU have completely disappeared in an extreme scenario. A time series analysis was used as an auxiliary variable (ceteris paribus) for various factors, which will be examined in more details below to predict how the trend observed in the data is likely to continue. Time is to be interpreted as a modification parameter for the transmission from analogue to digital.

$$
\mathrm{y}=\mathrm{f}(\mathrm{x})=-351,87 \mathrm{x}^{2}-1085,7 \mathrm{x}+237879
$$

where, $x=1$ for year 2007 to $x=25$ for year 2031 .

The results indicate that, based on the development to dataset and by neglecting the influence of other variables, the analogue channel will be further diminished and regional access degraded. According to regression, the branch system will no longer exist in 2031. However, this trend can be interrupted or changed by economic, political, cultural, technological or by reaching a minimum level for customer care. In addition, of course, also due to customer demand. There are several reasons for the high number of branch closures. First, the high fixed cost burden resulting from the operation of branches (Köhler \& Lang, 2008). This leads to empty costs if the employees in the branch office are underutilized (Swoboda, 2004). Low branch utilization was also caused by a changed pricing policy of the banks. Advisory-intensive products were distributed through the branches, standardized products through other channels (Menrad, 2020). As a result, business activities gradually shifted and customers were encouraged to access the digital channels. Consequently, bank branches were reduced as capacity utilization shifted towards digital channels. Simultaneously, consumer behaviour changed, as customers increasingly used digital media, which also became attractive for the banking business. To investigate whether customers meanwhile prioritise a different banking access, the authors analysed customers' Internet banking access in more details. In this study, the authors consider Internet banking (sometimes termed online banking) as access via PC to the bank. The average online rate (Bhatnagar et al., 2000) has meanwhile risen significantly and is within the EU at $58 \%(+132 \%$ in 12 years and $+38 \%$ since 2013$)$. However, there is no uniform change, as Figure 2 illustrates.

While the Scandinavian countries already have an almost complete internet banking rate and customers certainly have confidence in the access channel, bank customers in the countries Bulgaria and Romania still make little use of this access point. Although the network exists in these countries, bank customers are not willing to do their banking online due to significant safety concerns (Bhatnagar et al., 2000). In many other EU countries, the willingness to act online has changed considerably in recent years. Particularly noteworthy is the development in the Czech Republic. Here, the availability of online banking has increased from $12 \%$ to $68 \%$ within twelve years. The development in Greece is also substantial. While the Greeks almost did not use Internet banking eleven years ago, the usage rate today is nearly seven times higher. Today, more than one-fourth of the Greeks are connected online to their banks. 


\section{Figure 2}

\section{Internet Banking users in the EU between 2007 to 2019}

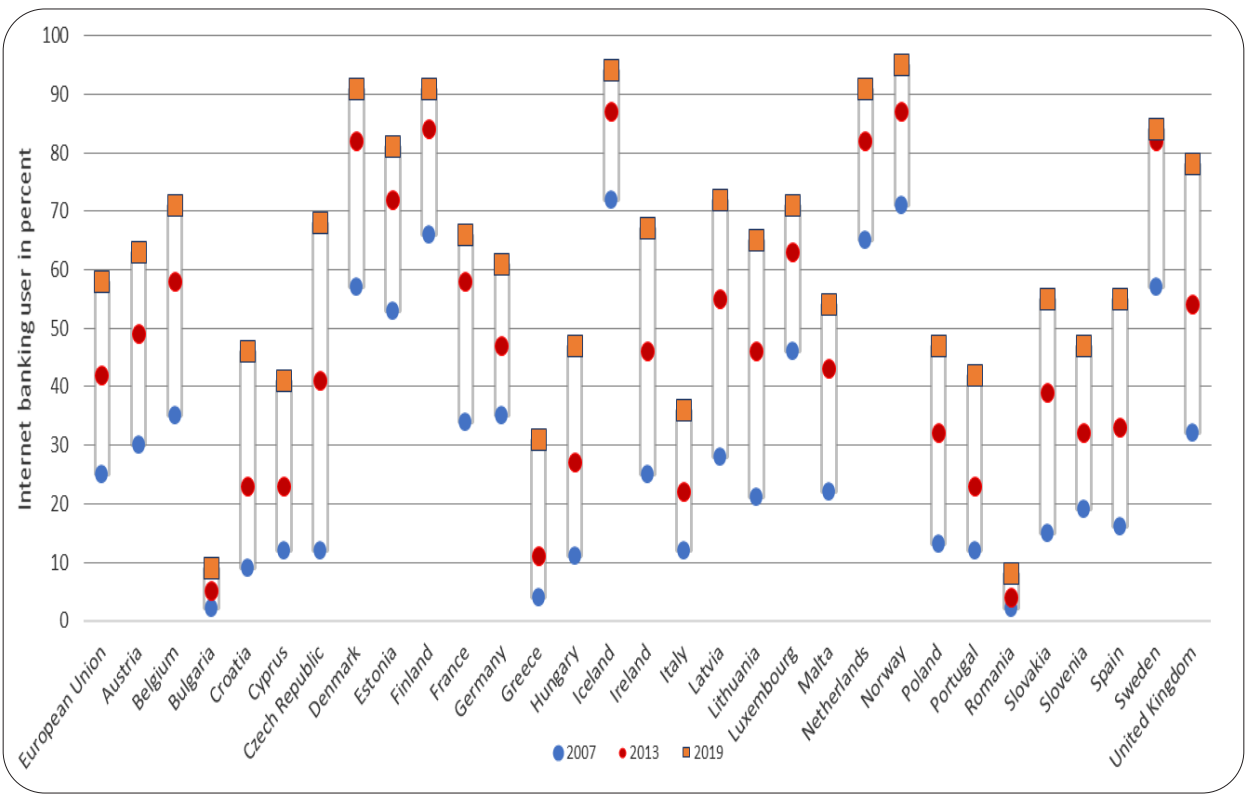

Source: Based on European Commission, 2020

Even though the customer usage rate at a younger age is greater than that of older EU residents (Figure 3), the development is almost synchronous. In the 45-54 age group, $59 \%$ of EU citizens already use Internet banking. It is also remarkable that $33 \%$ of Europeans over the age of 65 use Internet banking for transactions. Over three-quarters of the 25-34 age group use the Internet for their banking business, which is $37 \%$ more than twelve years ago. It is iastonishing indeed that the absolute number of users (age-independent) has increased significantly over the period investigated, but that the development is almost synchronous and the delta of the different age groups changes insignificantly.

Around $80 \%$ of highly educated EU citizens use online banking, while less educated citizens prefer other banking channels (Figure 4). The differences in education levels indicate that this factor shows a high relevance and is thus a suitable indicator for the use of this access channel to a bank. Another indicator with conspicuousness and high rates of change is average income. Nearly $70 \%$ of higher-income people use Internet banking. It is astonishing that low-income residents tend to use Internet banking significantly less. In fact, one could assume that low-income customers use standard services and high-income customers are advised in bank branches, but this does not seem to be the case. 
Figure 3

Internet banking users in the EU between, age comparison, 2007 and 2019

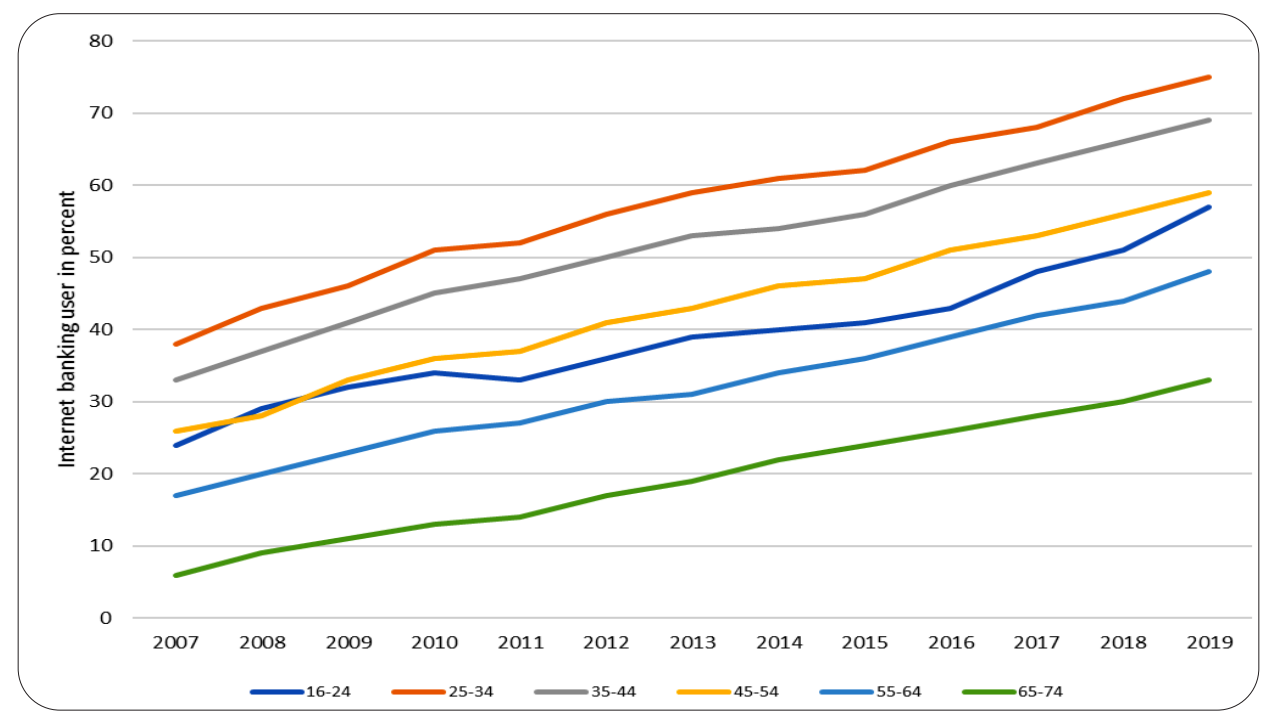

Source: Based on European Commission, 2020

Figure 4

Internet banking in EU, individual criteria, 2007-2019

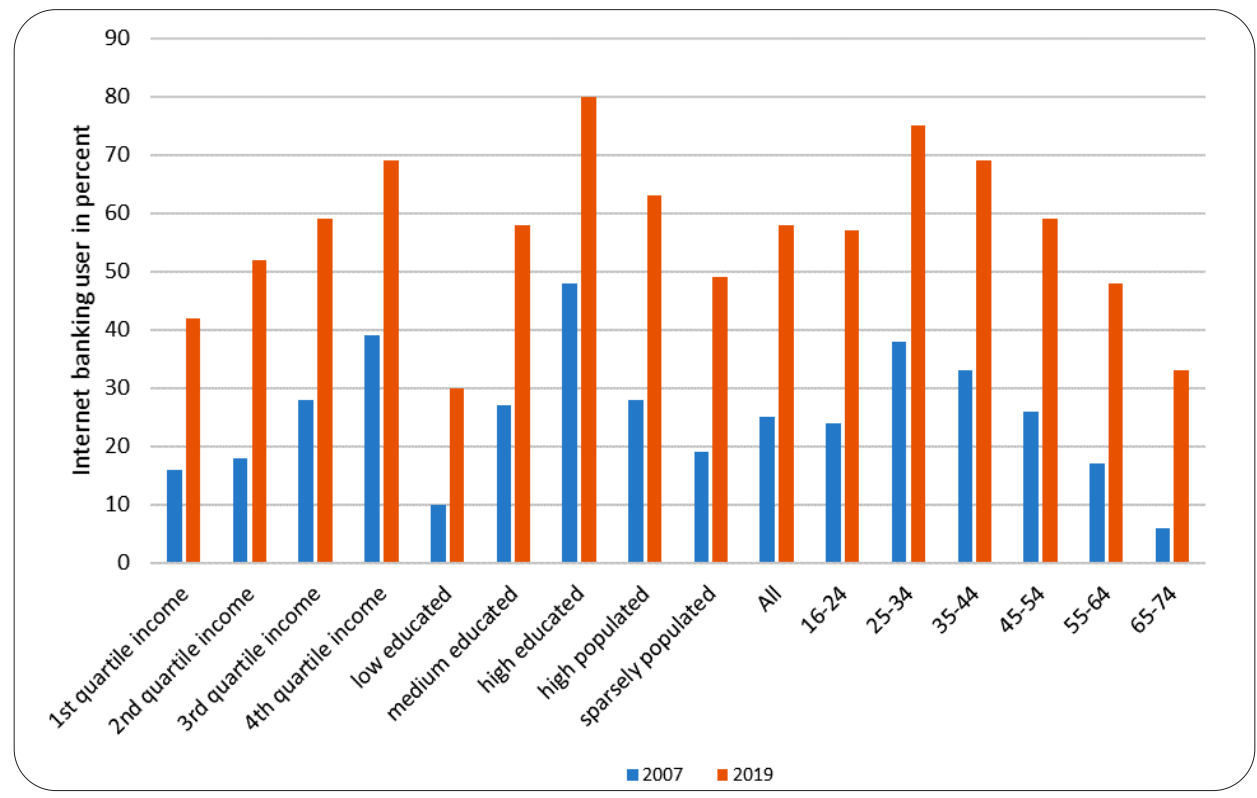

Source: Based on European Commission, 2020 
Digital banking does not only refer to online banking but increasingly also to mobile banking. Mobile banking is referred to as the interaction between customers and banks via a mobile phone, tablet or comparable, to do bank business at anytime from anywhere (Dablberg et al., 2008). Apart from the necessary conditions that require the operation of mobile networks, mobiles now offer the possibility of being free from spatial and temporal limitations. This provides a large convenience to the user and bank customers (Zhou, 2011). While security aspects severely limited the spread and acceptance of mobile banking in the past, the community has now come to terms with this technology. Banks have invested heavily in the security of digital channels in recent years, also in order to build customer confidence in this product field. The authors of this paper have conducted a global comparison in order to have an international benchmark in this fast-changing distribution channel of banks. The study examined bank customers' access to the bank via mobile phone and/or the Internet. A continental comparison was conducted and individual selected countries were highlighted. In addition, the authors have set a cluster delimitation on the available income of the bank customers. The results (Figure 5) show that in North America, the $\mathrm{EU}$ and parts of Asia, digital access to the bank is used intensively, whereas in other regions of the world, access is significantly lower. One third of the world's population uses digital access points to the bank.

Figure 5

Global comparison: Applied access to a bank account with a mobile phone or with the Internet during the past year

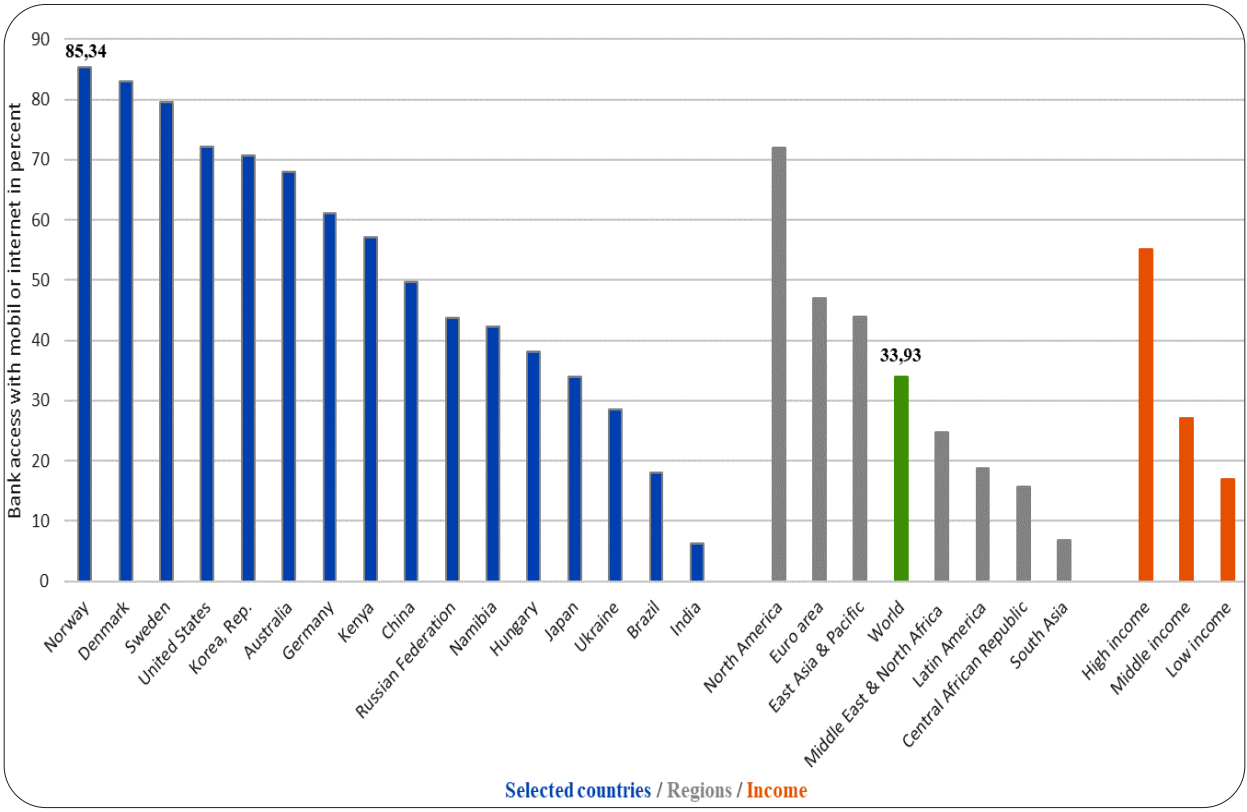

Source: Based on World Bank, 2018 
Figure 5 also illustrates that customer income is a relevant factor for the use of digital channels. Customers with higher incomes are more willing to interact with their bank via digital access than customers with lower incomes. Bank customers in the Northern European countries interact most intensively with their bank via digital channels, also in an international comparison.

Recent research addresses and validates the determinants of mobile banking usage. Trust plays an important role in influencing user behaviour as it uses only technology and no personal interaction (Gefen \& Karahanna, 2003; Grazioli \& Jarvenpaa, 2000). According to $G u$ et al. (2009) structural assurances are the most appropriate way of building trust with the intention of promoting mobile banking. Customers will only make extensive use of mobile banking free of fears and uncertainty once they have gained trust and transaction security (Gu et al., 2009; Mahmoud, 2016). To promote this technology, banks must prevent fraud and customer damage. This can be achieved in particular through guarantees and warranties (Gu et al., 2009). Other research has shown that satisfaction and perceived enjoyment play a relevant role (Agrebi \& Jallais, 2015). The success of mobile banking is very different regionally and culturally. For a variety of reasons, mobile banking is already highly successful in North America, Europe and East Asia and in parts of Africa. In developing countries, especially in Africa, mobile banking could play a strong role, providing a way to overcome financial exclusion and physical distance by enabling the local population to conduct financial transactions (Baptista \& Oliveira, 2015). In many developing countries with a high rural and agricultural structure, the poor infrastructure for a retail banking network is difficult and inappropriate. However, mobile communication networks and mobile banking now offer the opportunity to venture into remote rural areas. Within just a few years, Kenya has become a leading country for the penetration of mobile banking, and mobile banking was instrumental in giving non-banks access to financial services (Lee et al.; Rouse \& Verhoef, 2017). India needs to catch up considerably (Sha \& Mohammad, 2017). In summary, customer interest in digital banking access has increased significantly in recent years. Although there are significant regional differences, customers have accepted new technologies in banking. The current literature on new technologies and their use and adoption in the banking business has focused very intensively on the consumer side. Different customer groups, satisfaction and loyalty with the bank's offering and a very intensive analysis of the adoption perspective were examined by different researchers (Hanafizadeh et al., 2014; Hernandez \& Mazzon, 2007).

The bank's side of the adoption process has rarely been investigated by scientific studies. Statements are more frequently provided in the annual reports of banks or in perspective studies by consultants (Ernst \& Young AG, 2018; Wyman, 2018). The following section presents a concept for measuring the degree of digitization $(G)$ on the banking side in order to intensify this previously neglected aspect in the future. It will be measured with the sum of all digital banking action (YDIG ) divided by the sum of all banking service income $(\mathrm{Y})$.

$$
\mathrm{G}=\mathrm{G}\left(\mathrm{Y}^{\mathrm{DIG}} / \mathrm{Y}\right)
$$


We define all banking services as the total banking income (Total net revenues, Y). Banks usually measure their income by interest rate income (Yinterest), by commission and by fee income (Ynon-interest).

$$
\mathrm{Y}=\mathrm{Y}^{\text {interest }}+\mathrm{Y}^{\text {non-interest }}
$$

The first part (interest rate income, Yinterest) is mainly in indirect connection with the digitalisation process and is usually presented as "Net interest income after provision for credit losses" in the income statement. This income depends on the difference between credit rate (icredit) and the deposit rate (ideposit). Some banks have now standardized, digitalized and automated parts of the interest business, such as the consumer credit business, using scoring models and platforms, allowing interest income to be more accurately calculated. The second part of the income (service income, Ynon-interst) is independent of interest rate and usually presented as the "Total noninterest income" in the income statement. This income essentially originates from transmitting of money (payment services, remittances), commission income, brokerage and others. This income group is directly related to the banks' digitalisation efforts and can be linked to them to a considerable degree. These revenues are usually generated by processes within the bank and therefore can be aggregated into digital and analogue processes. Some parts of the Total noninterest income are income, but not directly attributable to digitalisation, therefore we define another YOTHER-NON-INTEREST. To these groups we include positions such as "Net gains (losses) on financial assets/liabilities"

$$
\mathrm{YD}=\mathrm{Y}^{\text {interest }}\left(\mathrm{i}_{\text {credit }}^{\mathrm{D}}+\mathrm{i}_{\text {credit }}^{\mathrm{A}}-\mathrm{i}_{\text {deposit }}\right)+\mathrm{Y}^{\text {non-interest }}-\mathrm{Y}^{\text {other-non-interest }}
$$

where, iDcredit is the interest rate originated from digital interest business and iAcredit from analogue interest business. The dependent variable YDIG can then be very precisely measured, evaluated, compared, benchmarked and controlled. As shown above in this paper, the bank can evaluate customer attributes such as age, income, education, region, population density and others and initiate targeted digitalisation measures in order to convert analogue transactions previously preferred by customers into digital transactions. Thus, for example, the bank result achieved in a certain customer age group can be evaluated in relation to total banking income but also to total digital income.

$$
\begin{aligned}
& \mathrm{G}=\mathrm{G}(\text { YDIG Agegroup / Y) } \\
& \mathrm{G}=\mathrm{G}(\text { YDIG Agegroup / YD) }
\end{aligned}
$$

\section{DISCUSSION}

The initial analysis of bank density revealed that bank branches in the EU are being reduced and thus the density of branches is decreasing. It can be assumed that this trend has not yet been arrested. Should the development of previous years continue in the same trend in the future, the branch system of banks within the EU will disappear in year 2031 and banks will have lost their regional access to customers using branch 
operations. In order to investigate alternative customer access to the bank, the development of Internet banking was analysed. A very heterogeneous development was observed. Overall, this customer access point to the bank has developed positively in all EU from 2007 to 2019. However, the dispersion of customer usage is significant. While in some countries customers use the Internet almost completely for their banking transactions, in other countries it is not yet popular for banking. Overall, bank customers in the EU have expanded their Internet banking activities. It has been determined that individual criteria such as age, income, region, population and education have an influence on the willingness to act digitally in the banking business. It is also evident that digital banking is being used to varying degrees by customers worldwide. It was found that there are considerable country-specific differences in the use of digital banking. Even within world regions such as Europe, the differences are remarkable. The Scandinavian countries continue to be the region with the strongest affinity to digital banking, whereas Bulgaria and Romania continue to face significant country-specific problems in operating digitally in the banking business. In addition, an international comparison on the use of digital banking channels revealed that customers' income is a relevant indicator. Within the EU it can be stated that bank customers with a good education are more likely to be enthusiastic about digital banking than bank customers with a lower level of education. In addition, the authors have found that in areas of the EU with a high population density, the willingness to engage in digital banking is greater than in areas with a lower population density. The study reveals that there is still considerable potential for digital development in banking in countries such as India and Brazil, but also in world regions such as Latin America, Central Africa and South Asia. In summary, it is remarkable that one third of the global banking population already interacts digitally with their bank via the Internet or by mobile phones.

In contrast to the previous line of research, which examines the adoption behaviour of the customer, a concept was presented that examines the degree of digital technology on the part of the bank. This enables banks to dynamically review their existing customer portfolios and immediately identify changes in customer behaviour. Banks are enabled to follow and benchmark their own development, but also to analyse the development of their customers. Knowledge of the relevant factors for customer behaviour is fundamental for banks, as this is the basis for individual customer marketing. The factors age, income, education, region, culture, and others have been examined in the context of the use of digital access and can be both granularly analysed at the portfolio level of the bank and managed factor-specifically in the future.

\section{CONCLUSION}

The objective of this study was to investigate customer behaviours with regard to the acceptance of digital channels and technologies in the banking business and, based on this, to focus on the bank rather than on customer adoption only. For this purpose, 
the banking market in the EU was examined in more details. Evidence has revealed that banks are increasingly reducing local customer access using branches and customers are increasingly using digital access points to their banks. However, customer behaviour is not consistent, as the dispersion in the use of digital channels varies significantly, although the overall direction of development is equal and positive. Banks have lost the direct access to the customer initially and must rebuild this probably painstakingly and service-oriented in future. In complement, it can be concluded that additional research is needed to analyse country-specific aspects in order to examine the change from analogue to digital banking.

Additionally, this study presented an approach to measure the degree of digitalisation of a bank. The approach requires a very precise controlling within the bank. The annual financial statements only show the aggregated data and not the detailed customer data. In order to achieve an exact result, it is necessary to separate the customer data from the bank's income data. If bank controlling is able to provide such accurate data, the degree of digitalisation is very valuable and provides precise impulses and approaches for sales and management. Based on this information, the bank is able to control efficiently the digitalisation process.

\section{REFERENCES}

Agrebi, S., \& Jallais, J. (2015). Explain the intention to use smartphones for mobile shopping. Journal of Retailing and Consumer Services, 22, 16-23. https://doi. org/10.1016/j.jretconser.2014.09.003

Ajzen, I. (1985). Behavioral Interventions Based on the Theory of Planned Behavior. In Kuhl J., \& Beckmann J. (eds.) Action Control. SSSP Springer Series in Social Psychology. Springer, Berlin, Heidelberg.

Baptista, G., \& Oliveira, T. (2015). Understanding mobile banking: The unified theory of acceptance and use of technology combined with cultural moderators. Computers in Human Behavior, 50, 418-430. https://doi.org/10.1016/j. chb.2015.04.024

Bhatnagar, A., Misra, S., \& Rao, H. R. (2000). On risk, convenience, and Internet shopping behavior. Communications of the ACM, 43(11), 98-105. https://doi. org/10.1145/353360.353371

Black, N. J., Lockett, A., Ennew, C., Winklhofer, H., \& McKechnie, S. (2002). Modelling consumer choice of distribution channels: an illustration from financial services. International Journal of Bank Marketing, 20(4), 161-173. https://doi. org/10.1108/02652320210432945

Christensen, C. M., Raynor, M., \& McDonald, R. (2015). What is disruptive innovation? Twenty years after the introduction of the theory, we revisit what is does - and doesn't - explain. Harvard Business Review 12, 1-11.

Dahlberg, T., Mallat, N., Ondrus, J., \& Zmijewska, A. (2008). Past, present and future of mobile payments research: A literature review. Electronic Commerce Research and Applications, 7(2), 165-181. https://doi.org/10.1016/j.elerap.2007.02.001 
Davis, F. D. (1989). Perceived Usefulness, Perceived Ease of Use, and User Acceptance of Information Technology. MIS Quarterly 13(3), 319-340.

Ernst \& Young AG. (2018). EY-bankenbarometer-2018: 10 Jahre nach der Finanzkrise - Aufbruchstimmung? http://docplayer.org/72825500-Ey-bankenbarometer10-jahre-nach-der-finanzkrise-aufbruchstimmung.html

European Banking Federation (2020). Structure of the Banking Sector: Number of domestic bank branches. https://www.ebf.eu/facts-and-figures/structure-of-the-banking-sector/

European Commission (2020). Personen, die das Internet für Internet-Banking genutzt haben - Eurostat. http://ec.europa.eu/eurostat/web/products-datasets/-/tin00099

European Parliament and of the Council (2002). Directive 2002/65/EC of the European Parliament and of the Council, 90/619/EEC, Directives 97/7/EC, 98/27/EC

Fishbein, M., \& Ajzen, I. (1975). Belief, attitude, intention and behavior: An introduction to theory and research. Addison-Wesley series in social psychology. Addison-Wesley.

Gasser, U., Gassmann, O., Hens, T., Leifer, L., Puschmann, T., \& Zhao, L. (2017). Digital-banking 2025. Universität St.Gallen. https://www.alexandria.unisg.ch/ publications $/ 253962$

Gefen, D., \& Karahanna, E. (2003). Trust and TAM in Online Shopping: An integrated model. MIS Quarterly, 27(1).

Grazioli, S., \& Jarvenpaa, S. L. (2000). Perils of internet fraud: an empirical investigation of deception and trust with experienced interne - Systems, Man and Cybernetics, Part A, IEEE Transactions on. IEEE Transactions on Systems, Man, and Cybernetics - Part A: Systems and Humans, 30(4), 395-410.

Gu, J.-C., Lee, S.-C., \& Suh, Y.-H. (2009). Determinants of behavioral intention to mobile banking. Expert Systems with Applications, 36(9), 11605-11616. https://doi.org/10.1016/j.eswa.2009.03.024

Hanafizadeh, P., Keating, B. W., \& Khedmatgozar, H. R. (2014). A systematic review of Internet banking adoption. Telematics and Informatics, 31(3), 492-510. https://doi.org/10.1016/j.tele.2013.04.003

Hernandez, J. M. C., \& Mazzon, J. A. (2007). Adoption of internet banking: Proposition and implementation of an integrated methodology approach. International Journal of Bank Marketing, 25(2), 72-88. https://doi. org/10.1108/02652320710728410

Köhler, M., \& Lang, G. (2008). Trends im Retail-Banking: Die Bankfiliale der Zukunft - Ergebnisse einer Umfrage unter Finanzexperten (ZEW-Dokumentation, No. 08-01). ZEW - Zentrum für Europäische Wirtschaftsforschung, Mannheim

Lee, J. N., Morduch, J., Ravindran, S., Shonchoy, A. S.,, \& Zaman, H. (2021). Poverty and Migration in the Digital Age: Experimental Evidence on Mobile Banking in Bangladesh, American Economic Journal: Applied Economics, 13(1) 38-71. https://doi.org/10.1257/app.20190067

Mahmoud, A. S. (2016). Mobile Technology in Banking Process. International Journal of Engineering Science and Computing 6(3), 2290-2294. 
McKechnie, S. (1992). Consumer buying behaviour in financial services:: An overview. International Journal of Bank Marketing, 10(5), 5-39. https://doi. org/10.1108/02652329210016803

Menrad, M. (2020). Systematic review of omni-channel banking and preview of upcoming developments in Germany. Innovative Marketing, 16(2), 104-125. https://doi.org/10.21511/im.16(2).2020.09

Messerschmidt, C., Berger, S., \& Skiera, B. (2010). Web 2.0 im Retail Banking: Einsatzmöglichkeiten, Praxisbeispiele und empirische Nutzeranalyse. Gabler Verlag, Wiesbaden

Rogers, E. M. (1962). Diffusion of Innovations. The Free Press of Glencoe Division of The Macmillan Co., 60 Fifth Avenue, New York 11, N. Y., 1962. xiii+367pp. $14 \times 21 \mathrm{~cm}$. Price \$6.50. (1963). Journal of Pharmaceutical Sciences, 52(6), 612. https://doi.org/10.1002/jps.2600520633

Rouse, M., \& Verhoef, G. (2017). Mobile banking in Sub-Saharan Africa: setting the way towards financial development. MPRA Paper 78006, University Library of Munich

Sha, N., \& Mohammad, S. (2017). Virtual banking and online business. Banks and Bank Systems, 12(1), 75-81. https://doi.org/10.21511/bbs.12(1).2017.09

Sousa, R., \& Voss, C. A. (2004). Service quality in multi-channel services employing virtual channels. London Business School, London

Swoboda, U. C. (2004). Retail-Banking und Private Banking: Zukunftsorientierte Strategien im Privatkundengeschäft. (3. vollst. überarb. Aufl.), Bankakademie-Verlag, Frankfurt am Main

Taylor, S., \& Todd, P. A. (1995). Understanding Information technology usage: A test of competing models. Information Systems Research, 6(2), 144-176. https:// doi.org/10.1287/isre.6.2.144

Tornatzky, L. G., \& Klein, K. J. (1982). Innovation Characteristics and Innovation Adoption- Implementation: A Meta-Analysis of Findings. IEEE Transactions on Engineering Management. 29(1), 28-45.

Venkatesh, V., \& Davis, F. D. (2000). A theoretical extension of the technology acceptance model: Four longitudinal field studies. Management Science, 46(2), 186-204. https://doi.org/10.1287/mnsc.46.2.186.11926

Walter, G. (2003). Kundenmanagement im Privatkundengeschäft von Banken. Zugl.: Regensburg, Univ., Diss., 2003. Bankinnovationen: Vol. 13. Universitätsverl. Regensburg

World Bank. (2018). Database. http://databank.worldbank.org/data/reports. aspx?Id=8312c83c\&Report_Name=interesting-data-for-interesting-corridors

Wyman, O. (2018). Bankenreport Deutschland 2030: Noch da! Wie man zu den 150 Deutschen Banken gehört. https:/www.oliverwyman.de/content/dam/oliver-wyman/ v2-de/publications/2018/Feb/OliverWyman_GermanBankingReport_2018.pdf

Zeithaml, V. A., Parasuraman, A., \& Berry, L. L. (1985). Problems and Strategies in Services Marketing. Journal of Marketing, 49(2), 33-46. https://doi. org/10.1177/002224298504900203 
Zhou, T. (2011). An empirical examination of initial trust in mobile banking. Internet Research, 21(5), 527-540. https://doi.org/10.1108/10662241111176353

Corresponding author:

\section{Michael MenRad}

Szent István University Kaposvár Campus

Doctoral School in Management and Organizational Sciences

H-7400 Kaposvár, Guba Sándor utca 40.

e-mail: michael.menrad@web.de

(C) Copyright 2020 by the authors.

This is an open access article under the terms and conditions of the

Creative Commons attribution (CC-BY-NC-ND) license 4.0.

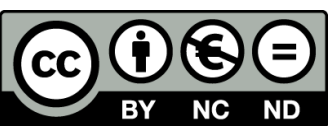

